Rev. bras. Ci. Soc. vol.2 no.se São Paulo 2006

\title{
The romantic drive and human sciences in western culture
}

\author{
Luiz Fernando Dias Duarte
}

\begin{abstract}
Modern Western culture is based upon the tension between a basic universalism and its permanent romantic counterpoint. Science is one of the main expressions of the universalistic attitude and the romantic genius dealt actively with it, criticizing and transforming it in many different ways. The emergence of modern 'human sciences' (originally conceived of as the Geisteswissenschaften, or 'moral sciences') is due to this tension, in the sense that they came to provide a sense of reality and knowledge very different from that prevailing in the pristine universalistic ideology. The themes of 'difference', 'totality', 'uniqueness', 'flow', 'drive', 'experience', and 'understanding' inspired or challenged the great founding fathers of the human sciences - eventually in contradictory directions. They remain nowadays as powerful as ever, either as the necessary rationalization for any anthropological research or as the channel for the so-called 'post-modern' speculations. To make them explicit and understandable is the task of this article.
\end{abstract}

Keywords: Romanticism; Human Sciences; Universalism; Individualism; Post-Modernism.

As so many other fundamental categories of our culture, the term 'romanticism' suffered an enormous extension and trivialization ever since its emergence, between the eighteenth and nineteenth centuries. Much was written on the meanders of that history, full of revelations about 
our ideological structure. There is a canonic work by Isaiah Berlin that scrutinizes in a carefully empiricist way that challenging polysemy (cf. Berlin, 2001).

My position here will be - to the contrary - deductive. I propose from the beginning a clearly defined concept of what I consider 'romanticism' to be. I will present a general picture of the ideological derivations of this phenomenon through the nineteenth century and I will indicate very summarily how the emergence and evolution of Western human sciences is inserted in it highlighting its points of continuity and divergence.

The position on which this proposal is based is that of an anthropologist, that is, someone that seeks to understand human experience from the point of view of its sense or meaning through 'cultures', in a comparative manner. This implies, in the first place, assigning a structuring quality - and not simply a residual one - to the idea that anthropology was conceived, and is cultivated, within a specific culture that may be called 'modern Western', since that epithet involves two qualities habitually dear to natives as part of their own, basic, worldview.

For an anthropologist - therefore a cultivator of the human sciences of this modern Western culture - what is more important is to acknowledge the strategic position of that instrumental analytic category, when trying to explain the dynamics of the cosmology within which we move - which is precisely ours, and not that of any other and far away society. As controversial as may be the use of the notion of 'one culture' and - even more - of 'our culture', that assumption - that I speak within a web of meaning common to all ideological actors henceforth mentioned and certainly common to all my readers - is an essential conceptual scaffold for my demonstration.

II

The hypothesis of a modern Western culture is not supported solely on the anthropological assumption of a collective sentiment or representation of cultural communion. It is also supported on the presupposition that its web of meaning is discrete and structured - and that it may be described through the invocation of some recurring and critical ideological principles.

Louis Dumont (1972), in his classic work comparing Indian culture to Western culture, suggested that an 'ideology of individualism' was the most important of these structuring ideological 
principles. He confirmed or combined in that definition - among many other scattered clues in Western social thought - elements of analyses from K. Marx (on liberal-bourgeois ideology), from E. Durkheim (on individualism or organic solidarity), from F. Tönnies (on Gesellschaft), from H. S. Maine (on contract societies), or even from Max Weber (above all on modern rationality).

That ideology is constituted and asserted in the Western world through very complex mechanisms and processes I cannot account for in this space (see L. Dumont, 1965; Duarte and Giumbelli, 1994). Its public hegemony would only be complete in the limit of the eighteenth century's great transformations, with the creation of the North American and French republics. In its strict sense, the ideology of individualism is above all a political ideology, relative to the value of the free and equal individual, autonomous citizen of the new nation-states in formation. It had as corollaries other concomitant ideological principles, with more general - epistemological or cosmological implications. We may sum them up under a wide label: the ideology of universalism.

Alexander Koyré published a very important work on the transformations of Western cosmology in the seventeenth century, titled From the closed world to the infinite universe (Koyré, 1976). That title emphasizes the emergence of a new conception of the world, to be called 'universe'. It is the basis for universalism. It is above all a representation, a new representation, of a limitless world, either temporal or spatial. An infinite - in all directions and senses. That world offers itself to human experience in an also limitless way, thanks to the belief in reason's ability to set a permanent dialogue with the empirical through human sensory and sentimental experience, so advancing cognitive and technical control of the world available to our species. We may call these characteristics rationalism and scientism, as active parts of the universalistic horizon. That new cosmological orientation is complete if we underline its strongly materialist character. As this is a complex concept, with wide semantic scope, it may sound better to contemporary ears if we refer to its physicalist character. In effect, what prevailed was the representation that the new cosmos, the universe, was made up solely of physical, material or 'natural' elements (excluded the supernatural and the preternatural).

These are the major ideological elements of the 'great transformation' depicted by Karl Polanyi (Polanyi, 2001), which opens up our culture's modern dimension. That transformation was obviously accomplished through complex economic and political mechanisms, including the hegemony of capitalism, of big industry, the colonial order, liberal democracy and even the emergence of socialist ideals. But they only became the crucial elements of the new order as long 
as they expressed, responded to or did not collide with the set of principles here summed up in individualism and universalism.

\section{III}

A new web of meaning thus oriented our ancestors through the eighteenth century. Its disposition was frankly optimist and its fiercest defenders were rightly called illuminists, believing as they did in the defeat and extermination of the shadow that up to then had obscured 'humanity's march'.

Uneasiness about the new way of collective thought and action, at the side of that generous and fierce disposition to change, was already perceived in some segments of the European intelligentsia of the eighteenth century. The indictment of the 'evils of civilization' began to disseminate at almost the same time as hymns to its victory were composed (see Duarte, 1986). This denouncement tone was imaginarily fed from the representation of a lost past, given the very radical emphasis on the future that characterized the new order. Progress, the advance of all forms and behaviors was threatening, for it implied the disappearance of the old mores, the loss of qualities to which many adhered. That tone was already present in artistic movements, such as the sentimental English novel and the German Sturm und Drang of the eighteenth century, as well as in a good part of the work of J.-J. Rousseau - himself a notorious illuminist. The movement for the revalorization of nature and of the rural world - at a moment when industrial artifice and the urban way of life involved faster and faster the European populations - is inseparable of that reaction (see Thomas, 1987).

Parallel to this process of sentimental reaction, so to say, signs of an intellectual reaction with political implications emerge. In many cases, it will come to be known precisely as a 'reaction', that is, an active resistance to the changes brought about by the French Revolution and its corollaries to European societies. This movement is more clearly articulated in the world of Germanic culture. The philosophies of Herder, Hegel or Fichte testify, in different ways, to the critical attention to Enlightenment's horizon, and the disposition to offer alternatives to the excessively linear or materialist way of conceiving history on the part of English and French philosophers (or the Kantian Aufklärung). 
There are many possible lines of historical interpretation for the concentration of this movement in the Germanic cultural scene. They cannot be all reviewed here. I refer the rich literature in this respect (L. Dumont, 1991b; Gusdorf, 1976, 1982, 1984; Benz, 1987, among others). It is however necessary to mention the importance of the reformed religious scene of this Germanic reaction. Let us recall that this universe had already experienced Renaissance - in contrast to the Latin world through Reformation; that it had found in Luther's Bible the confirmation of its linguistic legitimacy, and that its intellectuals were strongly bound to academic theology studies - never suspected of illegitimacy, as in the French case.

Contemporaries already expressed the feeling of a certain specificity of German culture in the European scene, and Mme. De Staël's De l'Allemagne asserted and described it with a great sense of opportunity. That specificity lied to a great extent, as Norbert Elias (1975) sums up, dealing with the vicissitudes of the notion of 'civilization' in the German language, in the disastrous political and economic stagnation deriving from the Thirty Years' War, in the pronounced fragmentation of its constitutive political units and in the distance that the ruling 'courts' (and the aristocratic sectors that made them up) kept vis a vis local culture and academic intellectuals (distance even from the German language, as in the notorious case of the Prussian court in Potsdam).

In a general way, the most evident point of all these resistances and reactions is their reflex character, dependent on the dynamics of assertion of universalism. Herder (1997) is clear enough in this respect when calling his great work on the history of humanity 'another history', in a reference and direct opposition to that of Voltaire. Goethe's Theory of Colors (1970) was conceived as a term to term refutation of Newton's optics. The reevaluation of Shakespeare's work undertaken by young German dramatists willed to exorcise the rationalization and convention of French classicism. In the same way, the rediscovery of the gothic style allowed for an irony on the continuous manipulation of classic sources undertaken since the Renaissance as a resource for the rationalization of plastic forms and volumes.

\section{IV}

The reactive inspiration of the earlier manifestations of romanticism will at once get a fuller affirmative tone, with the strengthening of the voices and arguments, and the perception of the outlines of an all embracing collective movement. It is however fundamental to keep in mind that 
the reaction was precisely the first great characteristic of romanticism, as I define it here: resistance to and indictment of universalism with its rationalist and physicalist corollaries. That is, there is no way of understanding that movement unless we consider it as technically encompassed by universalism. Precisely opposing it term-to-term and systematically, it depends on it ontologically and at each step. Even in its most grandiose, expressive or systematic manifestations, we will find there the en creux reference to the ideology of unlimited linear reason and its derivations.

As the strength of the romantic critique never weakened the puissance of the universalistic ideal within our ideological horizon, although it contributed to make its effects infinitely more complex, we must acknowledge that the two forces came to operate from the beginning in a permanent tension. But not in a reciprocal or egalitarian way: romanticism is always the counterpoint, the second moment of a dynamics that surpasses and determines it. It embodies, in terms of Louis Dumont's model, the hierarchic, holist dimension of human thought, opposed to the ideology of individualism. This is why we could and should acknowledge as 'romantic' any fundamental counter-force in our cultural dynamics since the final part of the eighteenth century. We will see latter on, however, how complex this 'reaction' is and how the combination of the many items which it recurrently includes may lead to very different and often contradictory solutions.

The most encompassing of its constitutive dimensions is possibly that which refers to 'totality'. The ideology of individualism, as I mentioned, is precisely characterized by its emphasis on the 'part', on individuals articulated in political associations thanks to the action of some natural 'passions' and 'interests' (Hirschman, 1997). Universalistic ideology does not operate in a different way. Its original typical formula, that of Newton's cosmology, also presupposed isolated 'elements' (celestial bodies), articulated in systems due to the action of some natural force. The indictment of the loss implied by this fragmentation of the world, by this emphasis in the segmentation of the elements constitutive of all beings, is romanticism's basic formula. Loss above all of the specific sense that the simultaneous presence of the elements in totality would cause. The lost totality (to be restored) could - and can - be found at many levels. One of the former, historically, and full of implications for what came to constitute itself latter as an anthropology, is that of cultural totality. Herder gave it a canonic form when dealing with Germanic culture as a specific entity, lesser than Humanity but surely larger and more expressive than the individual entities that made up the peoples speaking German. There laid one of the most active foci of the ideology of the modern nation, as well as of the contemporary, anthropological notion of specific 
'cultures'. Already in its time, the explicit opposition was to the ideal of indistinct undifferentiated and egalitarian - juxtaposition of citizens as members of an abstract Humanity.

The value of totality, of holism, often assumes in romanticism the connotation of unity, above all in what respects the original states of entities or phenomena. A pristine unity from which historical differentiation could have evolved, with either positive or negative implications. The $U r$ prefix German for 'original' - was often added to the most varied categories to express that recurring ideological emphasis. It would be interesting to explore the sliding from this intrinsic pristine state to the idea of unity/totality and the permanence value expressed in the idea of 'eternal' (as in the famous Goethean locution: das ewig Weibliches - the eternal feminine). In effect, the alwaysreferred representation of 'romantic love' cannot be separated of the valuation of a lost unity that only 'love' allows to restore (or, better, to aspire to restore).

Another important manifestation of the emphasis on totality was the progressive assertion of the category 'life' in the conceptualization and understanding of natural phenomena. By contrast to the prevailing mechanistic mode in the then called physiology - a direct heir to the Newtonian model, on the basis of the inventions of blood circulation and the nervous system (see Figlio, 1975; Lawrence, 1979) - the emphasis on live beings as totalities in themselves became the support of all the bio-medicine of the nineteenth century, from the concept of 'organism' on.

We find the same emphasis at the origin of the ideology of modern art and artist. In contrast to analytic or pragmatic interpretations of phenomena of the human poiesis, an author as K.- $\mathrm{Ph}$. Moritz posited the indecomposable integrity of the artistic object, that which 'folds over itself', which is justified in itself, because of the very mode of association of its parts, and not because of its functions or isolated characteristics (see L. Dumont, 1991a).

There is a neglected dimension of the ideological tension relative to totality that may be summed up referring to the category of uniqueness. In effect, I use this term, following Louis Dumont, in a sense to which one seldom pays attention, although it is essential to the expression of some of our most important values. It expresses the idea that every discrete entity may be considered at the same time an individuality, that is, one among many other similar entities, and a 'unique' one, that is, a unit of totality in itself. The contradiction in the case is fundamental and inaugurating: the emphases in the character of part and whole are intertwined and subverted, generating the paradox of 'the whole in the part'. Everything I said about romantic totalities may slide to the idea of 
uniqueness: nations, cultures, organisms and works of art may only be understood as totalities insofar as they present themselves as unique in the sequences of beings of the same ontological level. The Leibnizian concept of the monad translates very well some aspects of romantic uniqueness, and that is why it is often mentioned as one of the remote ideological sources of the movement itself.

The explanation of the totality dimension is completed through reference to the idea of 'spirit'. The German category Geist embodies in a paradigmatic way that idea, perhaps through allowing beyond-the-Rhine intellectuals to avoid the 'spiritual' resonance so disturbing for universalistic values (above all in the Latin version of genius). In effect, the reference to the 'spirit' was a privileged form of expression for the idea that totality was more than the sum or juxtaposition of parts (as in the mechanistic model). Life itself, which warranted totality to organisms, by contrast to mineral life aggregates, was thus a more elementary form of the 'spirit'; and we can also say that Geist was higher life, more refined and sublime, characteristic of individual and collective human experience.

I will now examine the dimension of 'difference'. It consists in the emphasis on the nonegalitarian, hierarchic characteristic, distinct or specific, of entities among themselves. Something as a differential denseness of the world, or a differential distribution of value - obviously in frontal opposition to the equality postulate essential to individualistic ideas. The example of Herder's commendation of the German cultural specificity comes back to the fore. He emphasized not only this entity's totality, but also its specific difference, its distinctive quality (Eigenschaft) in relation to the other manifestations of the human spirit. This colored both synchronic and diachronic oppositions: the so characteristic historicity of romanticism is essentially due to the feeling of a 'spirit of the times' (Zeitgeist), never identical in its manifestations. The idea of 'intensity', to be almost always associated to that of uniqueness, cannot be separated from that structuring perception of difference. Each moment of an entity or of the dimension of a phenomenon has its own intensity, a quality from itself and for itself, which cannot be compared to those expressed in other times and spaces. It is one of the most important romantic legacies to modern human sciences, always reactivated under new denominations.

The emphasis on difference emerged very early in relation to more immediate questions of social life, in blatant opposition to the democratic postulate. I assume one of the most precocious to be that of the 'physiognomy' reworked by Lavater by the end of the eighteenth century. The theory, 
mentioned and endorsed by Goethe, proposed that the profile drawing of the human faces should express the level of subtlety or civilization of their subjects. Martine Dumont, in a lucid article analyzing this little known episode of the physical-moral Western ideas, suggests that this was an attempt at reintroducing, through the hand of a naturalizing scientific theory, traditional and discredited theories of the difference of political subjects (M. Dumont, 1984). No doubt, that was the case, but - in truth - it was much more than that: not only the rejection of the political egalitarianism characteristic of the French Revolution and of the first Napoleon, but also the rejection of any universalism, including its physicalist dimension. It aimed at reintroducing a 'physical-moral' measure, a new positive mediation between matter and spirit.

A third dimension to be examined is that of 'flow'. I want here to stress the emphasis in the permanently dynamic and movable quality of all phenomena and entities, in contrast to the stabilized consideration of the world, intrinsic to the universalistic model. It is obvious that Newtonian physics presupposed and essentially sought movement, but a movement expressed above all in a revertible temporality, typical of the physical-mathematical thought. Romantic temporality is sharply irreversible; at best it may contain the idea of cycles and recurrences (as Nietzsche's eternal one), never those of indifference or indistinction. The distinction due to an important late romantic as Henri Bergson between temps and durée possibly elucidates what I want to stress. Durée is irreversible and dense, differential. It is not to be measured through the common mechanism of a clock, but through inner sensibility.

Flow is a property of the inner condition of entities, not an external, objective measure. It is an attribute of each totality/unique being and therefore manifests itself in an essentially differentiated way among entities. But it is also differentiated in its own internal sequence: the successive moments of the very same entity are not identical among themselves. That differential character was often expressed through an image of vital time, of a cycle of birth, youth, maturity and death. A sole flux of different times; eventually renewable in another level or dimension.

The fundamental point of this entire dimension is its abhorrence of immobility - or of permanence as immobilization. This could be applied to inanimate matter in opposition to the higher value of life, for instance. But it served above all to qualify the true or legitimate human life. This should be characterized by a continuous ascending movement, a progressive flow. The German category Streben, the disposition to struggle to reach some ideal or proposal always ahead is very typical of the romantic theory of personhood. It animates the internal dimension of the process of personal 
formation, the famous Bildung; in itself necessarily a specific, unique, irreplaceable vital flow. The novel of formation (Bildungsroman) stages the vital flow metaphor in a paradigmatic way ever since Goethe's Wilhelm Meister.

The most achieved and precise formula of the preeminence of flow in romantic thought emerged in the human sciences with the concept of 'subjective culture' due to Georg Simmel (Simmel, 1971) in opposition to that of 'objective culture'. Such a concept sums up or exemplifies all the points I am developing, but sheds light particularly on flux, for the positive qualities of subjective culture are the very ones that institute it in temporality, in the flow of change, in the intensity of inner creation. The passage to the 'objective' is the fall down in stasis: live thought turns into book's pages, intention becomes institution, life forces waste into petrified forms.

One could say much about the flow dimension in what respects collective human phenomena. Romantic historicity is at the origin of most of the human sciences (from archaeology to linguistics, from history to psychoanalysis) and its major characteristic is this very obsessive attention to the implications of the passage of time, and above all of the differential passage of time. But I will come back to the theme latter on.

I selected as the fourth dimension of romanticism the concept of 'drive'. It is the idea according to which phenomena and entities, unique as they are - total and differentiated - and endowed of the ability of expanding in the vital, temporal flow, do not do this without an inner, special quality, entirely from themselves, that lends their Streben the qualities, rhythms, orientations that are specific to them - and not to others. This was called in German - at least since Fichte - Trieb, today conventionally translated as 'drive'. That inner disposition characteristic of vital entities evokes some attributes of the Aristotelian entelechy and of Spinoza's conatus, and characterizes the most essential element of organized life: its prospect as a feasible destiny. While its concept is today associated above all to psychoanalysis, due to the specific and systematic use of it on the part of Freud, its presence was much wider in romantic thought and it remains - even though not explicitly - 'driving' among us (Duarte and Venancio, 1995). One of its most conspicuous manifestations is that which in art will emphasize the expressive character that authentic creation has in relation to the artist's inner world (Taylor, 1989). The creative drive must find unobstructed its channels, in order for aesthetic form to fully flourish. And it must only be cultivated there where it is really felt as an uncontrollable drive, literally vital (R. M. Rilke's Letters to a young poet offers this point a masterly example). 
The fifth dimension is that of the privilege of 'experience'. This concept is a pillar of the polemics over rationalism since the seventeenth century, around the complex relationship between reason and experience in the production of human spirit or understanding. Empiricists and sensualists were so called for they conferred preeminence to the experience deriving from the relation of the human senses with the world, and scientism transformed the idea of generating knowledge through artificial and controlled experiments in the structuring image of the very scientific activity. These images were well known to romantics and thus cannot be fully dissociated from the sense with which the term came to be employed among them. Although the concept of Erfahrung conveys a dimension of sensorial experience, it points decisively to sentimental or affective, intimate, personal, passionate - finally, subjective - experience.

The emphasis on experience is the epistemological basis of romanticism. It implies the rejection of an absolute external objectivity in the process of knowledge or in scientific practice, in the name of a constant consideration of the subjective processes at stake in the relation to the external world. Goethe already formulated this proposal in his Farbenlehre: against an optics that took light and color formation as objective, universal processes, independent of human perception, he was ready to offer a systematic consideration of the ways in which human experience of light and colors was structured. The great development of the physiology and psychology of the senses and sensations in the German academic world during the nineteenth century (of which Wundt and Freud were epigones) testifies to the crucial role of that connection between objective and subjective.

The last dimension to be mentioned is intimately linked to experience. Romantics called 'understanding' (Verständnis, in German; verb verstehen) the method of knowledge that took into account the embeddedness of all acts in the existential, subjective dimension. It was opposed to the linear explanation, considered typical of the universalistic, objectivist process - insufficient and self-defeating to the romantic eye. The concept had enormous importance for the human sciences, crossing the work of many influential authors in history and sociology; mainly Max Weber (Weber, 1978), who described the characteristics of the method of Verstehen in its best known form to this day. 
Thus presented the general lines of what seems to me to essentially qualify romantic thought, I evoke some aspects of their joint development through the nineteenth century, without which it would be impossible to understand the complexity of the flowering of the human sciences; dependent as they are from this rich imaginary project.

From its earliest manifestations, romanticism has shown marks of the dilemma posed by the fact of its being encompassed by universalism: it should expose the excesses of materialism, the illusions of a naif objectivism, without either reestablishing the incontestable privileges of religion or mechanically returning to a mystic lost past. The value of the foundation of science, of the constitution of a systematic lay knowledge, was often preserved, and an entire tradition of dialogue with researchers, techniques and universalistic practices was established and maintained, meandering through specialties, universities, laboratories, techniques and doctrinarian emphases. In addition, that 'romantic science' (known in German as Naturphilosophie) influenced in its turn the most universalistic orientations in an extremely vivid manner, and the evolution of all sciences and not only human sciences - through the nineteenth century may be seen as a complex outcome of that interaction (Gusdorf, 1985).

From the beginning, however, other thinkers tried to establish a larger distance with regard to the Lights, underlining the insanity of those that condescended in dialoguing with reason's servants. Novalis is a good example of this tendency, criticizing Goethe, for instance, as excessively Olympian and integrated. I call these tendencies romanticism of the Lights and of the Shadows, the former closer to the reflexivity of its original ideology, the latter more distanced, radically replacing rational reflection with intuition, that so many times invoked and cited Anschauung. We may recall in this respect the contraposition of Goethe's famous and presumed last words in his deathbed: 'More light!', and the title of Novalis' most celebrated work: 'Hymns to the night'. They serve as a good example of the opposition I refer and that will deeply mark the fate of romantic thought and of modern Western culture.

That opposition will find its fundamental way of expression in the separation of art and politics, on the one hand, and science, on the other. Philosophy, more encompassing and complex, mediates Shadow and Light, allowing for the emergence of particularly unique formulas, as that of Nietzsche.

Romantic Shadow throve practically uncontested in the domain of aesthetic expression. Western art from the end of the eighteenth century to our days is essentially a manifestation of romanticism. All 
constitutive dimensions previously presented concurred to the establishment of its parameters and legitimacy conditions, particularly totality (under the form of the autonomy of the aesthetic), difference (under the form of intensity as authenticity's criterion), flow and drive (under the form of creative expressivism). The sole characteristic of this domain of our culture that may be somewhat linearly associated to universalism, while modulated by peculiar romantic inflections, is certainly the idea of a permanent temporal avant-garde.

The other realm where the romantic Shadow throve was that of politics. All proposals explicitly restoring any kind of legitimate or systematic political difference belong here. The conservative and reactionary thought of the nineteenth century presented many examples, more or less 'shadowy', of this type of manifestation, from Chateaubriand and De Maistre to Charles Maurras. But Nazi-fascism is certainly its acme. Although some particularly sinister aspects of Nazism may be best understood as a medical ideology rather than as political ideology, many of its ideological traits involve romantic imaginary dimensions, especially the preeminence of totality/unity and of a differentiated intensity.

It would be particularly difficult to sum up the complex philosophical destiny of the 'German ideology'. What is certain is that romanticism represents the touchstone of the entire post-Kantian, so-called 'idealistic', route, from Hegel to Heidegger, with its expressive power concentrated and its influence enlarged above all in Schopenhauer, Dilthey and Nietzsche. The latter presented a late synthesis of the ideological threads of romanticism so particularly dramatic that made his work the regular source of renewal of romantic inspiration throughout the twentieth century, to a much larger extent than any of both his predecessors and contemporaries. Perhaps this is still his role, although some of his heirs and commentators, as Michel Foucault or Gilles Deleuze, have become in their turn direct spokesmen.

The birth of tragedy is a particularly powerful example of the romantic articulation of Light and Shadow, for it combines the romantic spirit with a universalistic rhetoric argumentation (differently from latter aphoristic works, whose form adequately matches their romantic content). In that work, Nietzsche proposes a reconstruction of Western culture's major myth of origin: that of its Greek roots. The indictment of reason, of the logos associated to Socratic doubt, looms large in the work, overthrowing the inaugurating positive character of the universalistic narrative. The alternative positive position is occupied by these forces of collective expression presumed to be primitive, previous to the emergence of doubt and resentment; totalities full of intensity whose profile is 
scarcely perceptible through classic tragedy and historical references to Dionysus. Nietzsche manages to maintain the generic preeminence of the myth of the 'Greek miracle', with inverted internal signs: there is a lesson to be inherited from these ancestors, but it is not that of reason - an original and possible unreason instead, as a warrant of the authenticity of the whole, of unity, flow, difference, intensity and drive. It is within that enraged combination of pessimism and optimism that he characterizes himself as a privileged example of philosophical mediation of Light and Shadow.

The other late luminary of romantic philosophy that was to influence many generations of Western thinkers was Dilthey. It is a more severe and discrete influence, not always evident, present above all through the reflection of his use and systematic defense of the methodological opposition of the sciences of nature (Naturwissenchaften) and human sciences (Geisteswissenchaften). Dilthey was as much influenced by English empiricism as Nietzsche, but that influence came to be more clear thanks to the almost total prevalence of Light.

\section{VI}

We must acknowledge that the distinction between Naturwissenschaften and Geisteswissenschaften, which began to be established by mid nineteenth century, expressed already an internal modulation of romanticism, allowing for the epistemological partition of the initial monistic ambitions of Naturphilosophie. In effect, the influence of experimental sciences of a universalistic tone rapidly spreads at this time, and the German academic world receives the development of scientific research as dependent from but not subordinated to the romantic horizon and the ambitions of Naturphilosophie. The incipient opposition of a more mediated, objective research, turned to the external physical nature, and another, immediate in consciousness and subjectivity, turned to the specific human phenomena is to be partly seen as a response to these developments of a great ideological legitimacy.

Such developments did not follow, however, only an external stimulus. They also expressed an extremely important internal imaginary focus that I suggest to call a 'romantic evolutionism'. It is the representation, according to which the flow of totalities in search of affirmation (Streben) of their original impulse (Trieb) necessarily evolves from simple, plain, undifferentiated or rough levels to more complex, subtle, differentiated or elaborated levels. Such process was already 
expressed in the above-mentioned representation of the emergence of life (Leben) as the highest level of brute matter and of the emergence of the spirit (Geist) as supreme culmination of existence/experience. One is then able to understand that it was possible to attribute specific qualities to the sciences addressing each of these levels, of an intrinsically differential subtlety. That idea found a paradigmatic expression in the Hegelian Aufhebung, a passage from a certain state of entities to another superior, more 'spiritual' and encompassing, one - without loss of ontological continuity. Its translation as 'sublimation' only partially expresses a complex and intense semantic focus. We cannot fail to mention the generalized and lasting influence of this ideological vector - for instance, in medical vitalism or in Kardecist spiritualism.

This is a fundamental representation if we are to understand the organization of one of the major threads of the human sciences influenced by romanticism: Wilhelm Wundt's psychology.

The intellectual work of Wundt and his staff at the Leipzig laboratory is commonly hailed as the inauguration of a scientific psychology, by opposition to the philosophical speculation that would have characterized since the sixteenth century the academic exploration of the functioning of the human 'soul' or mind. As I have shown in another work (Duarte and Venancio, 1995), Wundt's research really aspired at a structuring scientific character. It was, however, a scientific character very different from that spread and consecrated by his Anglo-Saxon disciples. The major point to be emphasized is the separation of the psychophysiology of experience, which was his priority, and the 'psychology of the peoples' (Völkerpsychologie), that was to be developed with great effort after his dialogue with Dilthey, and the separation of the mediated from the immediate dimensions of the psychological object. The collective representations model precisely implied acknowledging the specific properties of a more complex and abstract collective psychological life. He thus turned to the constitution of a research method, to which he dedicated himself tenaciously, presenting original solutions that were to directly influence his disciples E. Durkheim and B. Malinowski, but also important contemporaries or successors, as William James and Franz Boas.

The peculiar combination of nature sciences and human sciences that characterized Wundtian psychology was paradigmatically expressed in the so-called principle of 'psychophysical parallelism', in a reference to Leibniz's postulate, according to which the phenomena of spiritual life are developed in parallel to those of natural, objective life, but without any local connections. They consist in two parallel lines, articulated at their thrust, but not in their elements. Such an integrated view, which emphasizes psychic life's totality and uniqueness, is generally considered as 
an expression of a romantic or holist tradition in the history of psychology, in opposition to the Anglo-Saxon illuminist/empiricist tradition (traced back to Locke).

That emphasis on the total, single, integrated character of the consciousness states was also expressed in other fundamental principles and methods, as those of immediate reality (Aktualität), creative synthesis and relative analysis. The preeminence of the category Trieb in his analysis of psychological phenomena also reveals the force of romantic influence, above all in the very peculiar way with which he associated it to the theme of human will.

Durkheimian sociology, commonly associated to universalism, as a function of positivism's weight in the definition of the social fact and of the tasks of nascent sociological research, is however a direct heir to many of romanticism's basic postulates. We already mentioned Durkheim's direct exposure to Wundt's thought, which he sought directly in Leipzig. Other acknowledged influences were equally important, as was that of Claude Bernard with his invention of the 'organism' as an 'internal milieu', so fundamental for both biological and human sciences.

One finds in Durkheim, as well as in Wundt, a general critique of the utilitarian or pragmatic way of producing a universalistic understanding of human phenomena. Durkheim retains the universalistic, even scientistic disposition, but he proposes to understand the sui generis character of social life with such emerging properties that differentiate it both from general nature and from human individual psychological nature. Totality of a new statute, 'social life' is to be understood as having special functioning rules that articulate social morphology and physiology, representations and shared values. The critique of utilitarian models involves in truth the critique of individualistic reduction, that is, of the assumption that collective life is only the result of the juxtaposition of free, equal and autonomous individuals. Durkheim was probably the first Western thinker to develop an explicit argument on individualism at the same time as an ideology and as a value: inaugurating and insurmountable; yet hindering access to sociological perception.

His contemporary Georg Simmel is another founder of the nascent sociology, whose work is characterized, on the one hand, by a high expectation about formalizing the understanding of societal forms, in the same sense as Durkheimian morphology, and, on the other, by a notable ability in making explicit the structuring values of individualist ideology and its revealing effect on the major dimensions of modern Western cultural life. His distinction between quantitative and qualitative individualism was most important in that sense. In the former category he summed up 
the original dimension of universalistic individualism, which constituted and understood the social universe through the combination of free-contracting, equal individuals, among themselves, in a political pact. And, in the latter, the specific contribution of the romantic theory of the person, with its characteristic emphasis in interiority, autonomy, in each monad's unique and authentic character. His masterly interpretations of phenomena such as love, money, modernity, and the city testify to the analytic power of his distinction between objective and subjective culture. As I mentioned before, that dichotomy at the same time expresses and serves as an instrument to a fundamental representation of romantic ideas: the opposition between form and life, the latter understood as an intrinsic dimension of legitimate human life, extended in a significant flow of original dispositions and determinations (Streben/Trieb).

Nascent anthropology may be considered a heir to the essential dimensions of romanticism. I privilege here two of its founding fathers, for their decisive contributions to the establishment of a canon of anthropological research: Franz Boas and Bronislaw Malinowski. In effect, the former is credited with the explicit invention of the idea of cultural plurality as an object for anthropological comparative analysis; the latter is taken as having invented anthropological fieldwork as a touchstone of the discipline's methodology. The Boasian concept of culture is clearly heir to the notion of cultural totality/unity prevailing in romanticism since Herder, applied to the entire realm of human experience and not only to civilization facts. Boas' struggle against physicalist and racialist reductionisms that characterized the Western academy by the end of the nineteenth century may also be seen as an affirmation of the superior qualification of the spirit (let us recall Goethe's beautiful poem about the Geist he transcribes in his preface to Ruth Benedict's Patterns of Culture) as a touchstone of cultural phenomena.

Malinowski has a peculiar position with regard to romanticism, given the common association of his explicit epistemology to a linear and materialist empiricism. Awareness to the importance of the romantic horizon in his formation and legacy to anthropology is, however, growing (Strenski, 1982). Because of the theme's width, I underline here the point that seems to me the most important and that I have already explored in another article about anthropology as a paradoxical 'romantic universalism' (Duarte, 2006). It concerns mostly the theory of fieldwork. In effect, Malinowski established the basic script for the definition of the anthropological fact as deriving from an extensive subjective experience of the observed social world, the only way of arriving at an effective understanding of the vital senses actualized in it. We have here a valuable combination of 
the totality, experience and understanding themes - clearly related to the preeminence of life and drive.

Two great romantic developments in Western human sciences will be left aside in this summary presentation. One of them - that of Freudian psychoanalysis - deserved a recent specific demonstration by Inês Loureiro, author of a masterly work on the matter (Loureiro, 2002). The other is that of history, deserving a study in itself, given the enormous importance of what is properly called historicism in the general context of romanticism and in the constitution of contemporary historical sciences. I only mention again Max Weber and his celebrated historical sociology as a particularly strategic example of such influence. While he distances himself, for many reasons, from the analytical style of his more explicitly romantic contemporaries (as Simmel and Tönnies, for instance), it is impossible to understand his strategy for the definition of the socially significant units in the history of rationality (both in The protestant ethics and the spirit of capitalism and in the trilogy on civilization's religions) and the definition of his Verstehen (understanding) method without a reference to the analytic points I mentioned as characteristic of romantic thought.

It would be instructive to examine under the same light the work of Norbert Elias, who can be considered as the latest of romantic sociologists. His understanding of the civilizing process cannot be dissociated from romantic evolutionism, with specific touches of its Freudian version and with a particularly noticeable weight of the idea of a historical drive. His way of understanding significant historical totalities is very similar to the Weberian 'spirit' (eventually redolent of Oswald Spengler's Herderian reifications in the Decline of the West).

\section{VII}

A last and superficial reference may be made to some contemporary developments. Romantic thought proper extends in a continuous tradition to the period of the Second World War, in philosophy as well as in the arts and sciences. The traumatic implications of Nazi domination over the Germanic cultural space, the exhaustion of the expectations of a generalized culture of Bildung in the West and the political defeat of authoritarian nationalistic theories imposed a new threshold to the tension between universalism and romanticism. 
The gradual return of romantic principles in Western thought took the form of what today is called post-modernism, that is, a critique of universalism in the name of uniqueness, intensity and experience. In spite of the semantic expressiveness of the native category, I think it convenient to characterize these new manifestations as a 'neoromanticism'. I emphasize thus the continuous presence of romantic values in the formulation of the contemporary philosophical and sociological problematic and - at the same time - its considerable unawareness of its determining affiliation due to some extent to the violent historical breach occurring by mid twentieth century.

Both psychoanalysis and social (or cultural) anthropology, which preserve more than any other discipline the structuring marks of the romantic worldview have almost completely lost the awareness of their romantic roots, its demonstration in need of a quasi-archaeological elucidating work. Today, romantic continuities proper combine with apparently new formulations of criticism to universalism, a process which seems to vow our disciplines more than ever to the tension between those two major characteristic ideas of our culture.

\section{BIBLIOGRAPHY}

BENZ, Ernst. 1987. Les Sources Mystiques de la Philosophie Romantique Allemande. Paris: J. Vrin

BERLIN, Isaiah. (2001), The roots of romanticism. Princeton: Princeton University Press.

DUARTE, Luiz Fernando Dias. (1986), Da vida nervosa (nas classes trabalhadoras urbanas). Rio de Janeiro, Jorge Zahar Editor/CNPq.

- (2006), 'Formação e ensino na antropologia social: os dilemas da universalização romântica', in Miriam Pillar Grossi; Antonella Tassinari \& Carmen Rial (eds.). Ensino de Antropologia no Brasil: formação, práticas disciplinares e além fronteiras. Blumenau, Nova Letra. 454p. (pp. 17-36).

DUARTE, Luiz Fernando Dias \& VENANCIO, Ana Teresa A. (1995), 'O espírito e a pulsão: o dilema físico-moral nas teorias da pessoa e da cultura de W. Wundt'. Mana. Estudos de Antropologia Social, 1.

DUARTE, Luiz Fernando D. \& GIUMBELLI, Emerson A. (1994), 'As concepções de pessoa cristã e moderna: paradoxos de uma continuidade'. Anuário Antropológico, 93.

DUMONT, Louis. (1965), 'The modern conception of the individual: notes on its genesis and that of concomitant institutions'. Contributions to Indian Sociology, 8. 
. (1991a). 'Du piétisme à l'esthétique: totalité et hiérarchie dans l'esthétique de Karl Philip Moritz', in Allemagne et retour, Paris, Gallimard. (ed.), Homo Aqualis II. L'idéologie allemande: France, . (1991b), Homo Aqualis II. L'idéologie allemande: France, Allemagne et retour. Paris, Gallimard.

DUMONT, Martine. (1984), 'Le succès mondain d'une fausse science: la physiognomonie de Johann Kaspar Lavater'. Actes de la Recherche en Sciences Sociales, 54.

ELIAS, Norbert. (1975), La dynamique de l'Occident. Paris, Calmann-Lévy.

FIGLIO, Karl M. (1975), 'Theories of perception and the physiology of mind in the late eighteenth century'. History of Science, 13: 177-212.

GOETHE, Johann Wolfgang. (1970), Theory of Colours. Cambridge, MA., The MIT Press.

GUSDORF, Georges. (1976), Naissance de la conscience romantique au siècle des lumières (col. Les Sciences Humaines et la Pensée Occidentale, 7). Paris: Payot.

. (1982), Les fondements du savoir romantique. Paris, Payot.

. (1984), L'homme romantique (col. Les Sciences Humaines et la Pensée Occidentale, 11). Paris, Payot.

. (1985), Le savoir romantique de la nature. Paris, Payot.

HERDER, Johann Gottfried. (1997), Auch eine Philosophie der Geschichte zur Bildung der Menschheit. Stuttgart, Universal-Bibliothek. Reclam.

HIRSCHMAN, Albert O. (1997), The Passions and the Interests. Princeton University Press

KOYRÉ, Alexandre. (1976) [1968], From the closed world to the infinite universe Baltimore, J. Hopkins University Press,. 313 p.

LAWRENCE, Charles J. (1979), 'The nervous system and society in the Scottish Enlightenment', in B. Barnes e S. Shapin (eds.), Natural order, Thousand Oaks, CA, Sage Publications.

LOUREIRO, Inês. (2002), O carvalho e o pinheiro: Freud e o estilo romântico. São Paulo, Escuta/Fapesp.

POLANYI, Karl. (2001), The great transformation: the political and economic origins of our time. Boston, MA., Beacon Press.

SIMMEL, Georg. (1971 [1908]), 'Subjective culture', in D. Levine (ed.), On individuality and social forms, Chicago, The University of Chicago Press.

STRENSKI, Ivan. (1982), 'Malinowski: second positivism, second romanticism'. Man, 17: 266271. 
TAYLOR, Charles. (1989), Sources of the self: the making of the modern identity. Cambridge, MA., Harvard University Press.

THOMAS, Keith. (1987), Man and the natural world: changing attitudes in England 1500-1800. Middlesex : Penguin.

WEBER, Max. (1978), Economy and society. Berkeley, University of California Press.

Translated by Plínio Dentzien

Translation from Revista Brasileira de Ciências Sociais, São Paulo, vol.19, n.55, p. 5-18, Jun. 2004. 